\title{
Study for Artist Henri Rousseau in the Perspective of the Unconscious: Centering on His Landscapes, Figures, Still-Life Paintings
}

\author{
Hyun Kwon Lee ${ }^{1}$ and Hye Ri Yoon ${ }^{2}$ \\ ${ }^{1}$ Hyun Kwon Lee Psychoanalytic Office, Seoul, Korea \\ ${ }^{2}$ Hye Ri Yoon Psychiatric Clinic, Seoul, Korea
}

\author{
무의식적 관점에서 본 화가 앙리 루소: 그의 풍경화, 인물화, 정물화를 중심으로 \\ 이현권 ${ }^{1} \cdot$ 윤혜리 ${ }^{2}$ \\ 이현권 정신분석 연구소, ${ }^{1}$ 윤혜리 정신건강의학과의원 ${ }^{2}$
}

In first paper, the author explained that Rousseau's series of jungles was a process which created an unconscious fantasy towards the mother Object. Based on this content, this paper analyzes various landscapes, figures, and still life paintings. Rousseau's unconscious was expressed in response to these three genres of reality conditions, resulting in the creation of his own individual space and style on the canvas. 'Naïve' and 'primitive,' which are art history experts' evaluations of him, label Rousseau's unique ability to interact with and express the unconscious like a child. Through the results of this analysis, the author argues that Rousseau's position in modern painting is important and was pivotal for the course of art history, and that the unconscious perspective provides the context for his artistic style.

Psychoanalysis 2021;32(2):52-63

KEY WORDS: Henri rousseau · Landscape painting · Portrait · Still-life · Unconscious perspective.

Received: April 1, 2021 Revised: April 9, 2021 Accepted: April 12, 2021

Address for correspondence: Hyun Kwon Lee, MD

Hyun Kwon Lee Psychoanalytic Office, 27 Guuigangbyeon-ro, Gwangjin-gu, Seoul 05115, Korea

Tel: +82-2-2138-7588, Fax: +82-2-2138-7589, E-mail: treeself@hanmail.net

\section{서 론}

본 논문은 앙리 루소에 대한 저자의 두번째 논문이다. 이전 논문에서 저자는 루소의 성격과 삶, 정글 연작을 분석하여, 그 의 삶을 지배한 어머니 대상과 관련된 무의식적 환상의 과정 들이 정글 연작에 표현되었음을 주장하였다(Lee와 Yoon 2021). 저자가 밝힌 내용은 다음과 같다.

루소의 정글 그림은 그의 어머니 대상을 복원(restoration)하고 소유하기 위한 무의식 환상(unconscious fantasy)의 과정을 시 각적으로 표현하였다.

This is an Open Access article distributed under the terms of the Creative Commons Attribution Non-Commercial License (https://creativecommons.org/licenses/by-nc/4.0) which permits unrestricted non-commercial use, distribution, and reproduction in any medium, provided the original work is properly cited.
저자는 어머니 대상을 향한 루소의 삶과 상응하여 움직인 정글 회화 분석을 통해, 무의식적 환상 및 역동이 그의 정글 연작 과정에 시각적으로 표현되었다고 주장하였다(Lee와 Yoon 2021). 동시에 루소는 정글 회화에서 개별적인 공간, 내러티브, 양식을 성취함으로 서양 모더니즘 회화가 지향하 고 있는 '개별적인 존재'에 대한 중요한 지점에 있음을 설명 하였다. 본 논문은 이런 분석을 바탕으로 풍경화, 인물화, 정 물화를 무의식적 관점을 중심으로 분석하여, 무의식적 역동 이 위 장르에 어떻게 영향을 주었고, 이 회화들의 모더니즘 에서 위치를 설명하려고 한다.

루소의 회화에 대한 모더니즘 회화의 위치는 다음과 같다. 세계의 주요 미술관에서 끊임없이 대중의 관심을 받고 있지 만, 모더니즘 미술사의 맥락에서 그는 아웃 사이더와 같은 소외된 인상을 받는다(Ireson 2005). 이는 아마도 1936년 뉴 욕 현대 미술관(MoMa)에서 '입체파와 추상 회화(Cubism and Abstract Art)'의 전시 카탈로그에서 보인 루소의 소개 


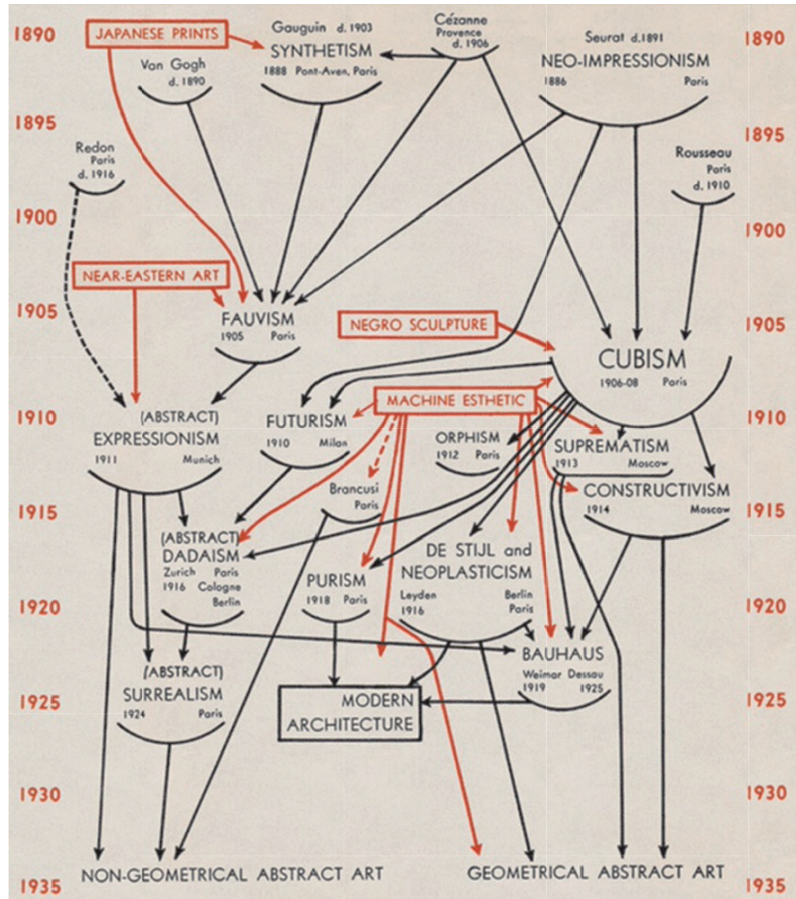

\section{CUBISM AND ABSTRAGT ART}

Figure 1. Diagram of Cubism and abstract art. Alfred H. Barr Jr. 1936.

때문일 것이다(Figure 1). 입체파를 미술사의 중심에 두고, 추상회화의 기원을 당시 미술사조에서 찾았던 역사적인 전 시회에서, 루소는 외진 곳에 홀로 위치한 예술가로 소개되었 고, 이후에도 그 맥락에서 벗어나지 못했다(Ireson 2005). 미 술사 및 평론계에서 루소에 대한 평가는 그에 대한 전문서적 이외에 그리 후하지 않다. 대표적인 미술사가인 Gombrich(1995)는 그를 거장이라고 했지만, 정식 교육을 받지 않 은 '일요 화가'로 소박하고 때묻지 않은 것을 추구하는 '이상 한 부류’라고 했다. 미술 평론계에서 ‘평면성’으로 모더니즘 회화를 규정한 Greeberg(2011) 역시 루소의 회화에 대하여 '원시(primitive) 회화', '일요일 회화', '소박(naive) 회화’로 부 르고, 역시 민속 미술의 한 부류로 생각하였다. 그는 "노년으 로 접어들어 그의 위트가 희미해진 때에야 비로소 만개한 '원 시 화가'가 되었다"고 평하였다. 그는 다소의 여지를 남겨 "원 시 회화라는 현상을 남부끄럽지 않은 것으로 만든 루소는 결 코 전형적인 사례가 아니며... ‘원시', ‘평민'이라는 범주는 너 무 좁아서 루소의 미술에 어울리지 않는다"고 하였다(Greeberg 2011).

미술사에서 무의식과 깊은 연관이 있다고 알려지거나, 무 의식을 중심에 두고 예술을 분석한 그룹에서 역시 분위기는
다르지 않다. 어떤 경우든 그들이 추구하는 미술사에서 루소 의 존재는 희미하다. 예를 들면, 모더니즘 회화에서 무의식 의 세계를 추구했던 초현실 주의를 연구한 저작들에서 브르 통(Andre Breton)의 몇몇 언급 이외에 루소의 회화는 관심 밖이었던 것 같다. 특히 동시대 미술사에서 무의식의 흐름을 포착해 적용해왔던 Foster(2020)가 최근 초현실 주의를 프로 이트의 관점에서 근접하게 재해석했는데, 이 저작에서도 루 소는 언급되지 않았다. 또한 정신분석 개념을 중심에 두고 모더니즘 회화를 분석한 대표적인 미학자인 Kuspit 등(1997) 도 역시 루소는 중요한 위치가 아니었다. 루소를 연구한 대 표적인 전문가들은 그의 미술사적인 중요성을 인지하고, 현 재 미술사적인 맥락에서 그를 연결시키려고 노력하고 있지 만 맥락과 연결 지점은 아직 불충분하다(Belli 등 2015; Ireson 2005; Stabenow 2006). 그의 회화는 지금도 많은 사람들 에게 경이로움으로 다가오고 작가들에게 영감을 주지만, 아 직도 그는 신비로운(mystic) 화가로 그의 회화 저편에 있는 무엇인가를 찾아야 할 필요가 있다(Ireson 2005).

저자의 이 논문은 이전 논문(Lee와 Yoon 2021)과 함께 '아 직도 밝혀지지 않는 루소 회화의 미지의 힘'을 무의식적 관점 으로 설명함으로 모더니즘 및 동시대 회화에서도 루소의 그 림자가 드리워져 있다는 것을 설명해 보려 한다. 이를 위해 먼 저 루소의 무의식적 환상의 역동이 그의 현실에 어떻게 침투 되어 그의 회화에 영향을 주었는지 설명을 할 것이다. 이를 위 해 본 논문에서 저자가 제시하는 기본 질문은 다음과 같다.

"루소의 무의식은 현실의 다양한 조건과 반응하여 어떻게 표현 될까?"

이 질문에 대하여 우선 저자는 루소의 풍경화, 인물화, 정 물화를 차례로 분석할 것이며, 이전 논문에서 설명한 그의 정신 역동 및 무의식 환상이 그의 3 가지 현실 상황에서 어떻 게 스며들어 표현되었는지 알아 볼 것이다.

저자의 일관적인 설명의 근거는 저자가 임상에서 경험하 는 무의식, 즉 자아 심리학 및 대상 관계 이론이다. 본 논문 에 주로 적용되는 이론적 틀은 Brenner가 주장했던 타협 형 성(compromise formation)이다(Brenner 1982). 이는 본능 적 욕동, 초자아, 불안, 방어 등의 무의식적 요소들이 현실과 반응하여 재조직되는 과정인데, 여기서 '현실'이 풍경, 인물, 정물의 다양한 조건으로 자극된다. 물론 타협 형성으로 예술 적 과정을 설명할 때 정신 분석에서 말하는 증상이나 꿈, 성 격 등과 차이점이 있다. Baudry(1984)는 이에 대하여 기술적 인 숙련도, 재능, 예민함 등이 예술의 독특한 속성으로 정신 분석의 환원적 공식으로 설명할 수 없다고 하였다. 
Table 1. Change of Modern Art in the perspective the unconscious

\begin{tabular}{lll}
\hline & \multicolumn{1}{c}{ Art of eras } & \multicolumn{1}{c}{ Modern to Contemporary Art } \\
\hline Story (Narrative) & Narratives of eras & Individual story or narrative. esp. unconscious fantasy \\
Space, Object & Space and object of the eras & Individual space and object. esp. unconscious space and objects \\
Art Style & Style of the eras & Individual Style \\
Time & From the Past & From the present \\
\hline
\end{tabular}

본 논문은 저자가 무의식적 관점에서 모더니즘 회화의 변화 과정을 위해 적용해왔던 틀을 적용할 것이다(Table 1). 시대를 대표하는 내러티브, 공간, 양식을 표현했던 전통의 방식은 이 시기를 기점으로 개별적 내러티브, 공간, 양식을 캔버스에 담 기 시작하는 것이다. 저자는 과거의 기준들에 '시간성'을 첨 가했다. 여기서 '현재로부터(from the Present)'의 의미는 현재 느끼는 감각으로부터 시작되는 회화를 뜻한다. 인상주의 운 동을 비롯하여 개별적 존재를 향한 서양 모더니즘 회화의 흐 름에서 시간성은 어떤 화가나 화가들의 그룹에게 중요한 요소 로 작용한다. 루소에 대한 이전 논문(Lee와 Yoon 2021)은 이 4 가지 중 무의식적 환상, 즉 개별적인 내러티브의 존재를 강 조하였지만, 본 논문은 루소의 회화 중 풍경, 인물, 정물화를 분석함으로 현재 감각의 순간에서 그가 성취한 개별적인 공 간, 양식이 무의식적 역동과 깊은 관련이 있음을 설명하려 시 도할 것이다.

그 과정을 통해 Lee와 Yoon(2021)을 포함해 루소의 회화 가 개별적 존재를 추구하는 모더니즘 회화에 중요한 위치에 있음을 확인할 수 있고, 무의식적 관점이 중요한 맥락임을 밝힐 것이다.

\section{본 론}

\section{풍경화}

\section{개별적인 내러티브}

루소 주변의 한가한 전원과 도시를 그린 풍경화는 루소의 전체 작품 중 가장 큰 비중을 차지한다. 그가 세관원으로 일 하던 시기부터 그려왔으며 현재 70여 점이 남아있다. 그는 당 시 화가들이 선호했던 화려한 파리의 풍경보다 주로 외지고 고요한 공간을 주로 그렸다(Stabenow 2006). 루소에게 풍경 화의 의미를 시사하는 1910년 예술 평론가 Arsene Alexandre 와 한 인터뷰가 있다(Adriani와 Köln 2001).

\section{〈인용문 1〉}

$\cdots$ 자연을 관찰하고 그리는 것만큼 나에게 행복한 것은 없습니 다. 당신은 상상할 수 있을 것입니다. 내가 교외에 나가서 매일

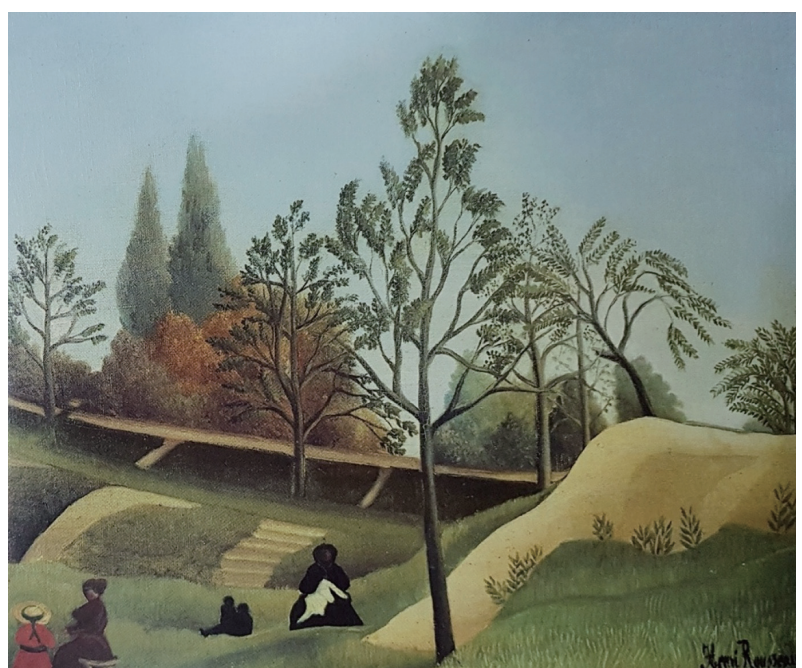

Figure 2. View of the Fortification (1896), $38 \times 46 \mathrm{~cm}$. Switzerland, Private collection.

태양과 녹색 잔디와 꽃을 보고 있노라면 나는 내 스스로에게 말 합니다. "사실 말이야, 이 모든 것은 나의 것이야"...

위 예문을 대표할 만한 그림은 1896년에 그린 Figure 2이 다. 흙으로 쌓여진 도심의 성벽은 방어의 기능을 하지 않고 주말에 쉴 수 있는 공간이다. 밝은 날, 나무와 녹색 잔디에서 한가하게 사람들이 쉬고 있는 장면은 위〈인용문 1〉의 마음 을 표현한 듯하다. 하지만 이전 논문에서 말했듯, 루소의 삶 은 가난과 질병, 주변의 비난 등 고통의 연속이었고, 정글 연 작이 그에게 그의 삶의 어려움과 대비되는 어릴 적 소망했 던 어머니 공간과 같은 무의식적 도피처였다는 이전 해석을 감안해서 볼 때(Lee와 Yoon 2021), 그에게 자연을 그리는 것 은 현실에서의 도피처임을 짐작할 수 있다(Le Pichon 1982). 또한 Le Pichon(1982)이 말한 주목할만한 자료들로, 루소가 자랐던 곳인 Laval과 Mayene을 관찰했을 때, 루소가 그렸 던 풍경의 장면과 소재들이 유사하게 등장했다. 이를 통해 정글 연작과 풍경화는 의식과 무의식적 층위가 다를 뿐이지 현실의 고통을 피하여 안식의 공간을 추구한다는 의식/무의 식적 목적은 비슷했다.

이 흐름은 풍경화 전반에서 유사하게 나타난다(Figure 3). 1909년에 그려진 이 풍경화 역시 한적한 부두에 루소 자신 


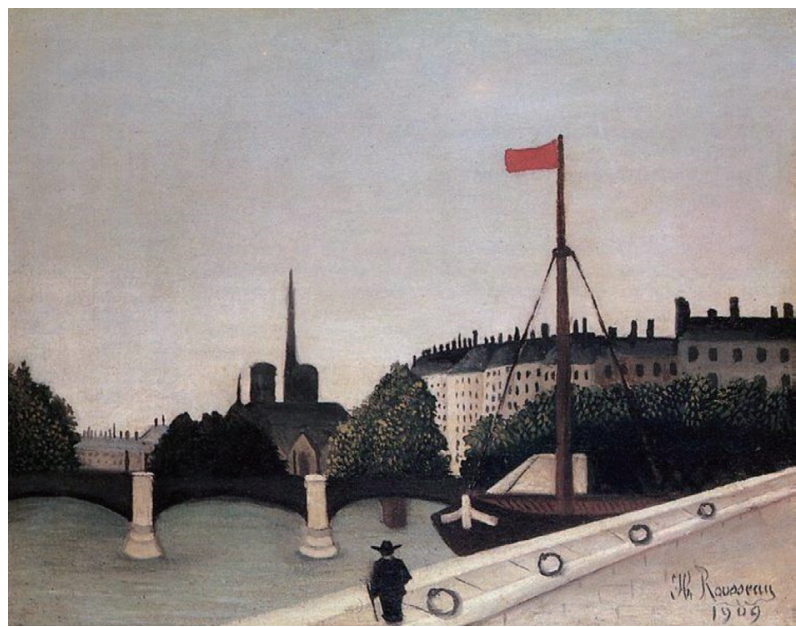

Figure 3. View of the lle Saint-Louis seen from the Quai Henri IV (1909), $33 \times 41 \mathrm{~cm}$. Washington DC, The Phillips collection.

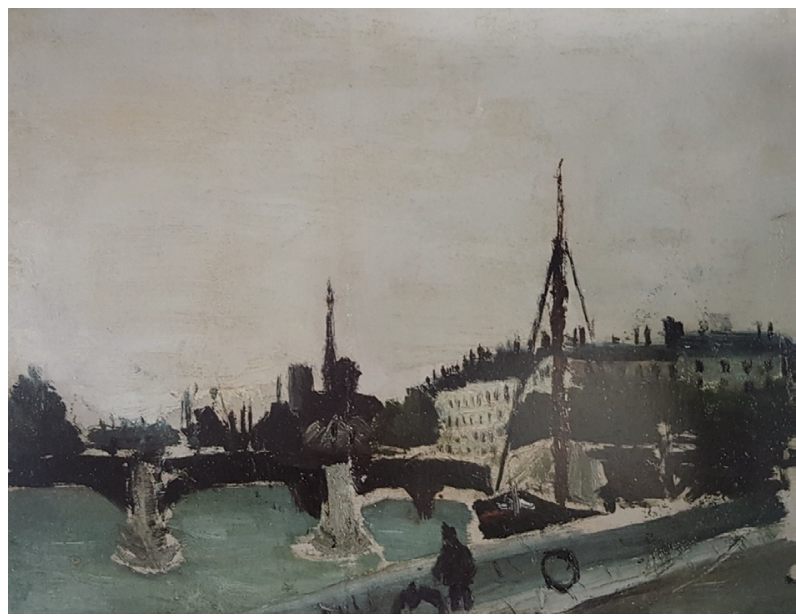

Figure 4. Study, View of the lle Saint-Louis seen from the Quai Henri IV (1909), $21.9 \times 28.3 \mathrm{~cm}$. Laval, Musee du Vieux-Chateau.

으로 보이는 신사가 외롭게 바다와 건물을 덮고 있는 나무 숲을 보고 있다. 건물과 나무, 다리, 사람들 모두 단순하게 캔버스의 표면에 표현되고 있다. 하지만 이렇게 '어린아이' 의 그림과 같이 소박하고 단조롭게 보이는 표면은 그가 이 그림을 위해 그렸던 습작을 보면 그의 풍경이 완성작과 큰 차 이가 있었다(Figure 4). 남겨진 몇개의 습작들을 검토해 보면 완성작에 그려진 회화가 직설적인 감정의 표현이 아님을 알 수 있다. 전반적으로 거친 붓질과 어두운 톤의 색, 덧입혀진 색채들은 당시 마티스를 중심으로 한 야수파의 회화를 상기 시킨다. 야수파의 주된 흐름은 현재 느껴진 감정을 캔버스에 담는 것으로 이해가 되는데, 이 표현주의적 화풍의 흐름은 고 흐의 붓에서 원인을 발견할 수 있다. 다음 인용문은 고흐가 자 신의 감정 상태와 붓놀림을 설명한 편지이다(Gombrich 1995).

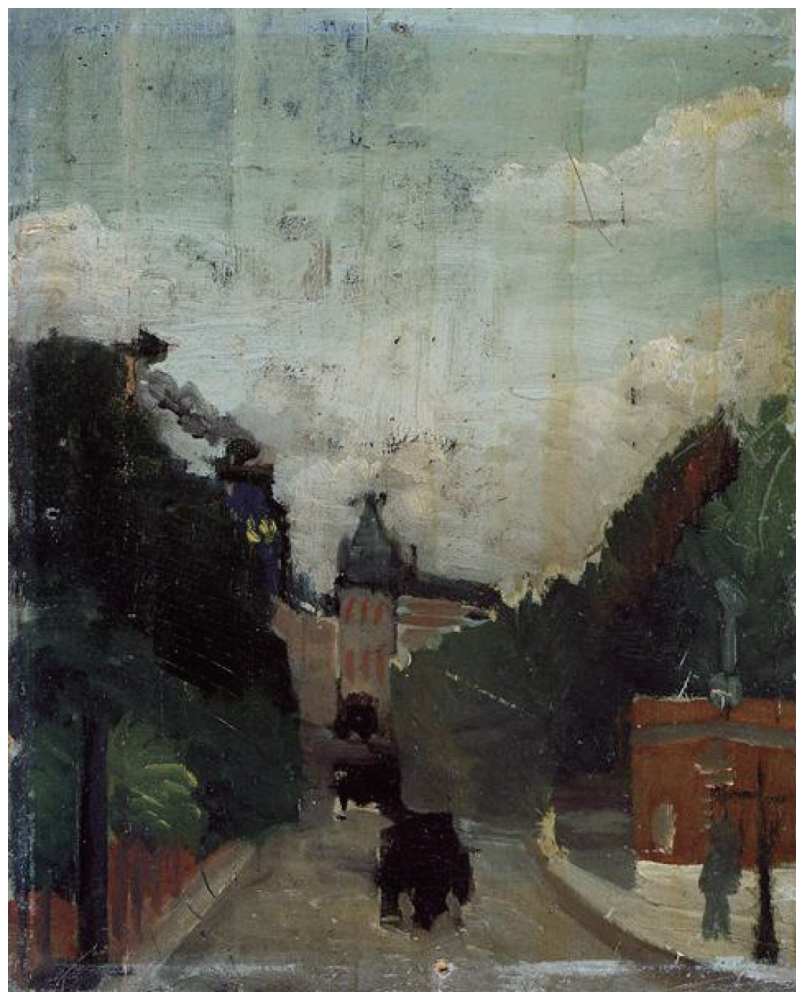

Figure 5. Study, View of the Palais du Metropolitan (1909), $27 \times 22$ $\mathrm{cm}$. Private collection.

\section{〈인용문 2〉}

$\cdots$ 때때로 너무나도 강렬한 그림에 빠져 나 자신이 지금 무엇을 하고 있는지 모를 때가 있다 $\cdots$ 마치 말을 할 때나 편지를 쓸 때 거침없이 단어들이 줄줄 쏟아져 나오듯이 붓놀림이 이루어지곤 한다 $\cdots$

이렇게 루소의 습작은 마티스나 고흐의 회화처럼 그가 공 간을 대면했던 순간에 느꼈던 격한 감정을 그대로 표현한 것으로 이해될 수 있다(Adriani 2001). 그러면 이렇게 어둡 고 혼란스러운 감정을 어떻게 설명할 수 있을까? 이러한 감 정의 상태는 그가 〈인용문 1〉에서 말했던 도피와 안식처로 서로의 공간과 상충된다. 또한, 또 다른 습작인 Figure 5의 그 림은 나무나 숲이 어두운 색채로 덧칠되어 복잡하고 두껍게 표현되고 있다.

이렇게 상충되는 부분에 대한 설명은 작업 방식을 이해하 는 것에서 시작할 수 있다. 루소는 습작 스케치를 작업실에 서 새로운 캔버스에 옮겨 완성하였다(Adriani 2001). 습작 (Figure 4)의 완성작인 Figure 3을 보면 대상 하나하나에 윤 곽이 생기고 단순해진다. 또한 대상들과 공간은 원근법이 아 닌 압축된 평면성을 띄게 되며, 그들은 하나의 캔버스에 새 로운 균형과 질서를 가지게 된다. 캔버스에 현실의 공간과 대상을 개별적으로 재구축하는 것이다. 이러한 과정을 통해 
습작의 어둡고 격한 감정은 응축되어 평면의 캔버스에 ‘단순 화’되어 재구조화 된다. 이러한 루소만의 메커니즘은 몇몇의 화가들에게 전해졌다. 대표적인 예로, 칸딘스키는 루소를 ‘위대한 리얼리즘'으로 말하며 1912년 청기사(Blue Reiter) 연감에서 〈형식의 문제에 대하여〉라는 글에 다음과 같이 적 었다(Stabenow 2006).

\section{〈인용문 3〉}

$\ldots$ 위대한 리얼리즘의 첫 단계는 그림에서 예술 외적인 장식을 제거해 평범하고 꾸밈없는 오브제를 단순하게 재생함으로써 작 품에 내용을 주고자 애쓰는 것이다. 이 방식으로 외형을 파악하 고, 그림 속에서 정의를 내리는 동시에 통상적으로 강요되는 미 를 제거하는 것이 사물의 내면의 소리를 드러내는 가장 그럴듯한

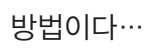

〈인용문 3〉에서 칸딘스키는 ‘단순하게’ 그릴 수 있는 루소 의 능력에서 단순함을 통해 루소가 성취한 '내면의 소리', 즉 루소의 회화 표면에 응축된 (의식/무의식적) 감정의 에너지 를 느낄 수 있었다는 점이다. 흥미로운 점은 이 '내면의 소 리'는 칸딘스키가 평생의 작업에서 회화로 포착하고자 했던 가장 중요한 주제였고, 이를 추상 회화로 표현하고자 했다는 점이다. 추상 회화의 가장 전면에 서있는 칸딘스키와 루소 회화와의 관계는 무의식의 인지(perception)와 표현이 추상 회화와 깊게 연관되어 있음을 시사한다. 이렇게 루소의 단순 함 속에 무의식적 감정이 내포되어 있다는 가능성을 기반으 로, 감정과 공간의 상충을 이렇게 설명할 수 있다.

1) 습작에서 나타난 어둡고 두꺼운 색채는 현재 풍경에서 느낀 고통의 감정들이 투사되어 덮인 것이다. 아마도 이러한 어두운 감정들을 던질 수 있는 곳은 바로 '어머니 대상이 존 재하는' 정글과 같은 나무 숲이 있는 공간일 것이다(Lee와 Yoon 2021). 루소는 그런 공간을 찾고 선택하여 자신의 감 정을 캔버스에 격하게 칠했다.

2) 하지만 그는 그 감정을 그대로 두지 않는다. 마치 정글 연작에서 어머니 대상을 복구하듯이 현실의 공간에서 대상 을 느낄 수 있는 ‘풍경’으로 복구한다. 그 구체적인 방법은 작 업실에서 그 감정을 ‘단순하게' 가공하여(processing) 재구축 하는 루소만의 양식으로 평면에 표현했다.

정리하면, (어머니 대상을 소망하는) 공간에 투사된 의식/무 의식적 감정이 습작에 나타나고, 그 감정은 작업실에서 단순 화된 양식으로 재구축되어 표현된다는 것이다. 따라서 이 내 용들과 앞에서 설명했던 내용들을 루소가 그렸던 공간을 통해 소유하려 했다는 점, Le Pichon(1982)이 밝혔듯 루소의 풍경 화는 그가 어릴 때 자랐던 공간과 유사하다는 점을 종합해서

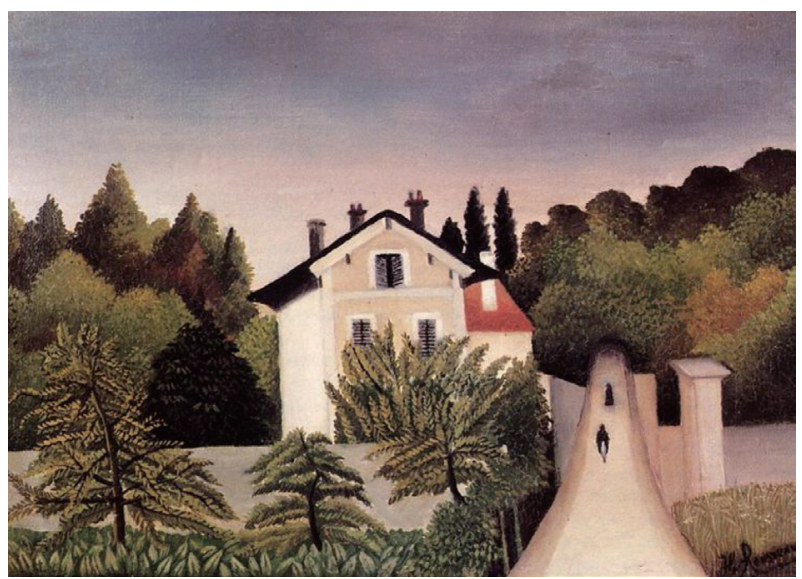

Figure 6. House on the Outskirts of Paris (1905), $33 \times 46 \mathrm{~cm}$. Pittsburgh, Carnegie Museum of Art.

루소의 풍경화는 정글 그림과 무의식 층위와 정도가 다르지만, 정글 회화처럼 어머니 대상이 있는 곳을 향하고, 또한 이를 복구 하려는 무의식적 소망이 표현되었다.

와 같이 결론을 내릴 수 있다. 이러한 결론을 설명하는 대표 적인 풍경화는 1905년에 그린 Figure 6이다. 역시 파리 외곽 의 한가한 곳에 나무와 숲, 집과 사람들이 조화롭게 배치되 어 있다. 특징적인 것은 숲으로 향하는 비현실적인 길인데 마치 길가의 사람들이 숲에 빨려 들어가는 듯하다. 또한 흥 미로운 점은 루소의 풍경화 연작을 관찰해보면, 그가 정글 그림을 그리는 시기에 다른 오브제들이나 공간은 단순화했 지만, 상대적으로 숲과 나무의 그림은 세세하게 그렸다는 점 이다. 이러한 내용으로 볼 때, 그는 작업실에서 펼쳐진 정글 연작만큼은 아니지만-그는 정글 그림을 그릴 때 실제와 환 상을 구분하지 못했다-, 의식이 작용하는 현실에 '무의식적 환상'이 침투하여 타협 형성된 표현임을 짐작할 수 있다. 즉, 그가 선택한 현실은 무의식이 침투하여 공존하는 '심리적 현 실(psychic reality)'인 것이다(Auchincloss와 Samberg 2012). 이는 앞의 〈인용문 3〉에서 칸딘스키가 루소의 회화를 위대 한 리얼리즘으로 칭한 것, 그리고 루소 자신을 현실주의자 (realist)로 여긴 것에(Belli 등 2015) 대한 무의식적 관점에서 의 이해일 것이다

\section{개별적 양식: 감정의 가공(processing)과}

\section{단순화(simplification)}

저자는 앞서 루소가 공간에 투사된 자신의 의식/무의식적 감정을 습작에 쏟아내고, 이 그림을 작업실에서 가공하여 재 구축한다고 설명하였다. 특히 루소의 풍경화에서 특징적인 '단순화'는 감정을 제거하는 것이 아닌 응축하여 표현한 것 이었고 그의 특징적인 개별적 양식(style/form)으로 이해된 
다. 이런 의식/무의식적 감정의 가공 능력은 자아 기능의 한 부분일 수 있다. 회화에서 감정을 처리하는 방식은 캔버스에 개별적 양식으로 표현된다. 화가의 감정과 가공, 색채와의 깊은 연관성은 마티스가 말한 아래 짧은 인용문으로 이해된 다(Essers 2006).

\section{〈인용문 4〉}

...색채를 무리하게 많이 사용을 하면 위력이 사라진다. 색채는 조직적으로 사용될 때만 표현력이 충분히 발휘할 수 있다. 그 강 도는 화가가 가진 감정에 상응한다 $\cdots$

마티스 전 생애 그림 양식의 흐름은 격렬한 감정과 색채 가 서로 상응하면서 표현과 단순화 사이에서 가공되었다. 그 의 회화는 말년이 되어감에 따라 극단적으로 단순해 졌으며 감정은 더 응축되었다. 마치 추상으로 향하는 듯한 단순함은 루소가 추구했던 양식과 겹칠 수 있다. 공교롭게도 마티스는 그를 따르는 후배 화가들이 루소를 추종하고 작품을 소개했을 때, 무관심하거나 때로는 화를 냈다고 한다(Adriani 2001).

이런 감정의 가공이 개별적 양식으로서 역할을 한 다른 예 는 세잔의 초, 중기 회화이다. 대상과 풍경에 강한 감정을 두 껍게 표현했던 세잔의 초기 작들은 인상주의 화가 피사로와 의 화풍을 동일시함으로 감정 표출의 힘이 가라앉았고, 세밀 한 붓의 획은 감각의 리듬을 가지게 되었다(Lee와 Yoon 2019). 이러한 유사성을 이해했는지 루소는 1907년에 열린 세잔의 회고전에서 "알다시피 여기 걸린 그림은 모두 내가 이미 완 성한 것이다"라고 했다(Stabenow 2006). 개별적인 자아는 개별적인 양식을 만들어내지만, 감정을 가공하고 재구축하 는 메커니즘의 유사함을 루소는 직관적으로 이해했다.

\section{개별적 공간: 공간 전이(Space transference)}

저자는 앞서 루소, 고흐, 마티스의 회화는 감정이 투사된 공간이 캔버스에 표현한 것이라고 설명하였다. 그리고 루소 를 분석한 결과, 그려진 공간은 루소의 무의식 역동과 깊은 연관이 있다고 하였다. 그의 풍경화는 정글 회화처럼 고통스 런 현실의 도피처로서 역할을 하는데, 층위의 차이는 있지만 무의식적으로 어머니 대상을 향한다는 유사성이 있다. 또한 정글 회화에서 어머니 대상을 복원하려 한 것처럼, 그는 습 작의 격한 감정 표현을 작업실에서 가공하여 재배치하였다. 이는 차이는 있지만 당시 고흐나 세잔과 유사한 메커니즘이 공유되었다. 저자의 관점에서 볼 때, 이 시기 위 소수의 화가 들-세잔, 고흐, 루소-로부터 캔버스에 표현된 '공간'은 상징 적이고 역사적인 원근법적인 공간에서 개별적인 공간, 즉 개 인의 감각과 감정, 그리고 이와 함께 무의식적 역동이 연결된
공간으로 전환되었다고 주장한다. 이렇게 (의식/무의식적) 감정이 내포된 공간을 시각화한 화가들의 작품 분석은 공간 에 대하여 무의식적 개념을 적용, 확장시키는데 도움이 된다.

프로이트는 공간에 대해서 다음과 같이 언급한 바 있다.

공간은 아마도 심리 장치(psychical apparatus) 확장의 투사 일 것이다. 그 어떤 파생체(derivation)도 가능하지 않다. 칸트의 선험(a priori) 대신에 심리 장치(일 것이다). 마음(psyche)은 확 장을 한다. 그 누구도 이에 대해 알지 못한다(Freud 1938),

이렇게 화가들이 캔버스에 표현한 '감정의 투사'가 심리 장치, 즉 이드-자아-초자아의 투사 개념으로 확장될 가능성 을 보여준다. 즉 외부 공간에 성격 구조-심리 장치-가 투사 되고, 작가는 이를 캔버스에 표현하는 것이다.

이와 연관된 무의식적 역동으로 이해하는 임상의 대표적 인 예는 다음과 같다. 보호 병동에 근무하는 저자는 이 폐쇄 된 환경이 환자마다 무의식적 상처를 자극하여 반복된다는 현상을 관찰한다. 즉 히스테릭 발작이 주증상인 40 대 남자 환자는 자신의 20 대에 갇힌 군대 환경이 자극될 때마다 발 작이 일어났었고, 분석 결과 이 발작의 기원 지점은 어릴 적 아버지의 강압적인 환경이었다. 정신증이 아니었지만 폐쇄 병동의 지속적 자극은 환자를 심하게 퇴행시켜, 당시 무의식 적 분노가 의식의 면에 나오는 순간 발작을 하게 되었다. 물 론, 이 분노를 의식화하는 치료 과정으로 발작은 나아졌지 만, 공간에 대한 막연한 공격성, 치료자를 군대 교관과 같은 전이 대상으로 보는 것은 폐쇄된 환경에서는 지속되었다. 이 간단한 사례와 몇몇 유사한 사례를 보았을 때, 저자는 주요 대상 뿐만 아니라 공간의 경험도 전이(transference) 현상으 로 반복하는 것이 아닌가라는 가설을 세우게 되었다. 이 개 념은 추가 임상 경험과 함께 다시 정리하여 설명할 것이다. 이러한 '공간 전이'의 시각적 근거가 루소의 정글 연작이나 풍경화가 아닐까 짐작한다. 단지 차이점은 무의식의 층위이 다. 정글 연작은-마치 꿈의 발현몽처럼-무의식적 소망을 현 실의 가능한 재료를 통해 재구성하였고, 풍경화는 의식에서 그가 선택한 공간을 재구성한 것이다.

\section{인물화}

무의식적 관점에서 루소의 풍경화가 현실의 요소 중 외부 공간이 주로 작용했다면, 인물화에서는 어떤 특징에 영향을 미쳤는지 알아보겠다.

1) 그는 평면성과 세부 묘사에 대한 지나친 집착을 보였다. 이러한 강박증적인 집착은 실제 인물을 그릴 때 치수를 제 고, 얼굴 톤을 맞추려 물감을 직접 피부 근처에 대곤 하였다. 
하지만 그가 그린 모델은 모두 이상한 모양이 되었고, 때로 는 퍼즐 조각을 맞춰놓은 것 같다(Stabenow 2006).

2) 아이를 그릴 때 아이 혼자 있는 모습을 그렸고, 얼굴은 아이의 얼굴이 아니라 마치 어른과 같은 표정을 보여준다. 신체 비율도 맞지 않는다(Figure 7).

3) 사진을 보고 그린 그림의 인물들은 모두 경직되고 비슷

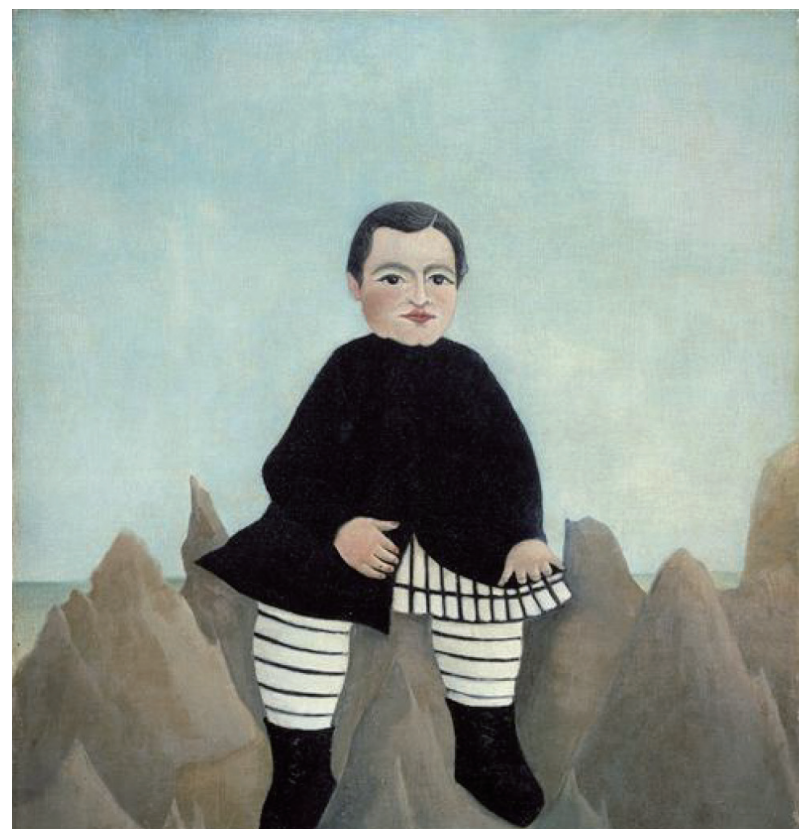

Figure 7. Boy on the Rocks, (1895 1897) $55.4 \times 45.7 \mathrm{~cm}$. Washington, DC, National Gallery of Art.
한 모습으로 보인다(Figure 8).

저자는 루소에 대한 이전 논문에서 루소의 자기(self)나 대 상의 분리(splitting)가 회화나 삶에 어떻게 영향을 주었는지 간단하게 설명하였다(Lee와 Yoon 2021). 여기서 루소의 자 기나 대상 표상은 정글 연작에서 다양한 조건과 자극과 반응 하여 분리(splitting)되 표현되었다. 이런 선행의 분석은 루소 의 인물화에서 대상 관계의 경험과 이론이 중요하게 작용할 수 있음을 짐작하게 된다. 루소의 대인 관계에 대하여 여러 의미 있는 내용들을 암시하는 Uhde(2018)의 관찰이다.

\section{〈인용문 6〉}

...루소는 주변의 사람들에 대하여 거의 아는 것이 없다. 그는 그들이 왜 바쁜지, 무엇을 하는지, 무엇을 생각하는지 모른다. 그 는 본능적으로 인간의 좋은 면을 찾고, 좋은 면을 강조하며, 다른 부분을 무시한다. 예를 들면, 루소를 처음 보았을 때, 나는 루소 보다 훨씬 어렸다. 어느 날 내가 루소에게 내 나이에 맞지 않은 성숙한 이야기를 한 적이 있다. 그 순간부터 나는 그의 눈에 내 나이보다 30 살이 많게 되어 그의 어린 시절을 함께 보낸 것처럼 이야기 하였다. 그는 나보다 나이가 많은 부인을 나의 딸처럼, 나 이가 많은 남자를 아들인지 물어보았다 $\cdots$

특정 자극에 현실 검증력이 무너지는 듯한 위 인용문은 Uhde(2018)에 의해 루소가 비교적 사회 생활을 잘해왔다고 묘사된 다른 여러 장면들-음악 학원에서 아이들을 가르치

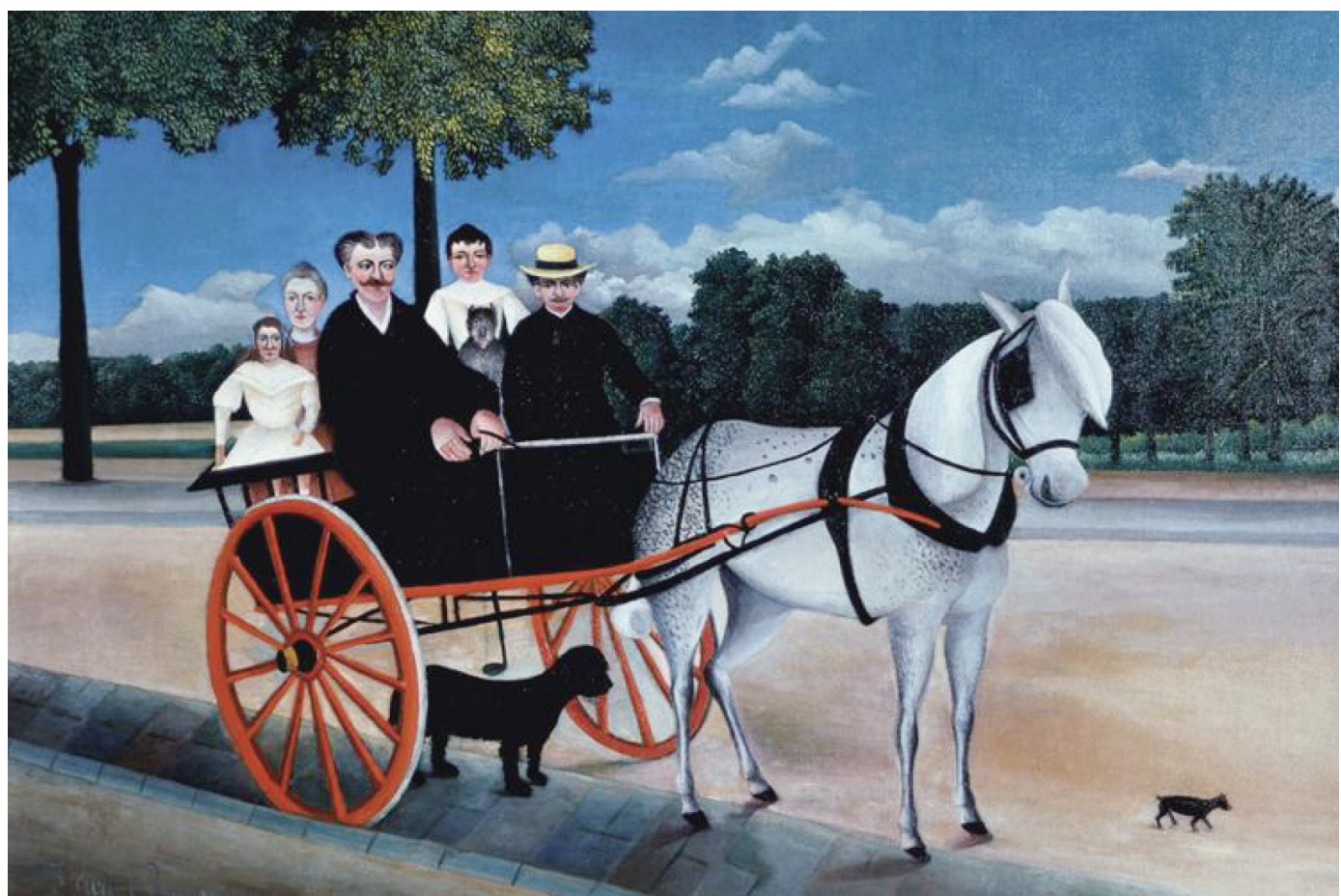

Figure 8. The Cart of Pere Juniet (1908), $97 \times 129 \mathrm{~cm}$. Paris, Musee de l'Orangerie. 


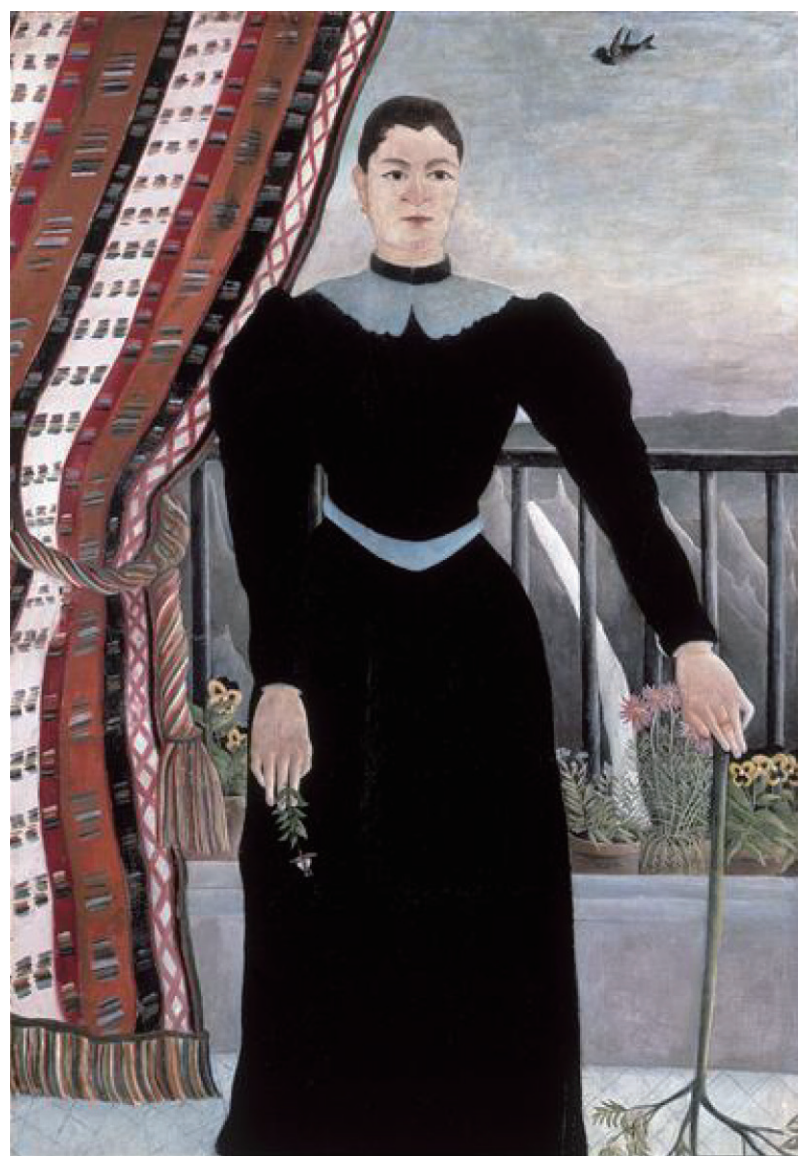

Figure 9. Portrait of a Woman (1895 1897), $198 \times 115 \mathrm{~cm}$. Paris, Musee d'Orasy.

고, 매주 파티를 열어 사람들과 어울리는 등-과 언뜻 보기에 맞지 않는 듯하다. 이에 대하여 Le Pichon(1982)은 루소가 상 상하거나 준비된 것만을 보기 때문에 그가 믿는 것만을 본다 고 하였고, 그의 '기억의 눈에 적응'된 것만 구별한다고 설명 하였다. 이러한 관찰과 설명 등을 종합하면 정신분석 임상에 서 중요한 '전이(transference)'의 개념이 유용하다. 피분석자 에게 분석가의 어떤 자극도 편집되어(edited) 피분석자의 억 압된 과거로 들어가는 문으로 작용하는 전이 현상으로 그의 대상관계와 대인관계를 이해하는 것이다. 이에 대한 실제 예 는 임상에서 흔하다. 분석가의 말, 안경 모양, 생김새, 옷 등 그 어떤 것도 피분석자의 중요한 대상과 연결되어(분리된 대상의 모습인) 과거의 시나리오로 들어가는 것이다. 물론 대인 관계에서 전이 현상은 보편적이지만, 루소의 경우 더 강하게 영향을 받는다는 것이다.

그러면 이렇게 대인 관계에서 하나의 자극으로(무의식적) 과거로 들어가는 전이 현상은 Figure 9에서 특징적으로 관 찰된다. Figure 9는 피카소가 1908년에 구입을 하였고, 이 ‘여성’은 그가 평생 옆에 둔 유일한 ‘여성’이라는 것이다. 이어
지는 인용문은 피카소가 이 작품을 구입할 당시의 상황에 대 한 설명이다(Adriani 2001).

\section{〈인용문 7〉}

..중고 가게에는 많은 작품들이 앞에 나열되어 있었다. 하나의 머리가 튀어나왔다. 강한 눈빛과 꿰뜷어보는 듯한 시선, 단호함과 명료함이 느껴지는 여성의 얼굴이었다. 캔버스는 거대했다...

인용문에서 피카소의 느낌은 루소 어머니의 분리된 대상 중 부정적인 부분에 대한 묘사와 유사하다. 이 그림에 대하 여 주문자가 누구인지 확실하지는 않으나, 이 그림에 대하여 루소의 위압적인 어머니 대상과 유사하다는 주장이 있다는 점에서 아마도 루소는 어떤 '여성'을 그릴 때, 그의 어머니 대 상의 위압적인 부분 대상이 투사되어(전이의 느낌을) 그린 것으로 짐작된다(Le Pichon 1982).

그림을 그릴 때 전이 현상의 적용은 인물화와 풍경화 모 두 적용되지만, 인물화를 그리는 조건에서 풍경화와 차이가 난다. 풍경화는 그가 비교적 자유롭게 공간을 선택할 수 있 었지만, 인물화는 의뢰 받은 경우가 많기 때문에 어쩔 수 없 이 대상을 대면해야 한다. 전이는 일반적으로 분석가와 접촉 시간이 길어질 수록 강하게 나타나므로, 이러한 점은 유사하 게 루소에게도 적용될 수 있는 것이다. 〈인용문 6〉에서 묘사 되었 듯, 어떤 자극에도 과거의 무의식적 충동이 지배하는 루소에게 당시 사람들이 원하는 실물과 비슷한 그림을 그려 야 한다는 요구 사이의 갈등은 필연적으로 발생한다. 의뢰자 는 그림을 보고 놀라고 때로는 버리기까지 했다. 그 충동과 억제는 아마도 위 인물화의 특징 중 1)의 내용인 실물에 대 한 강박적인 측정 등을 짐작하게 한다. 다시 말하면, 과거 대 상에 대한 충동과 의뢰자의 현실적 요구에 대한 갈등에 반 동형성으로 강박적 실물 측정을 한 듯하다.

인물화의 특징 중 2)의 설명은 다소 어렵다. 루소의 회화 에서 보이는 '아이 속의 어른'은 이미지는 명확하나 이유에 대한 논리적 과정을 밝히기에, 이에 대한 루소의 자료가 특 히 부족하기 때문이다. 하지만 위의 흐름대로 인물화가 루소 의 (의식/무의식적) 관계 표현이라면, 다음과 같은 가정을 할 수 있다. 루소 인물화의 흐름에서 현실의 모습과 차이가 심한 것은 현실의 요구가 다른 인물화보다 적었을 것이라고 추정할 수 있다. 아이와 대면은 어른보다 무의식적 충동을 억제할 필요가 없었을 것이다. 이러한 흐름에서 루소가 느껴 지는 '아이 속의 어른'은 정신분석 자체를 대변하는 듯하다. 즉 아이에게 성인이 보이는 도착적 성욕이 있다는 체계적인 첫 논문이 프로이트의 저작이며(Freud 1905), 순진해 보였 던 꼬마 한스가 성인 이상의 성적 상상력을 가지고 있다는 
경험은 이제 정신분석 이론과 경험에서 가장 중요한 근간을 이루고 있다(Freud 1909). 이러한 경험과 함께 정신분석 임 상에서 리비도의 고착(fixation)된 순간과 전이의 반복이 필 연적이라는 경험은 루소 회화에서 보이는 '아이 속의 어른'이 루소에게 과거 고착된 순간으로 퇴행할 수 있다는 상상을 하 게 된다. 이를 달리 말하면 '아이'와의 시각적 자극은 〈인용 문 6>에서 Uhde의 '성숙한 언어'의 청각적 역할을 하게 되 어, 루소 기억에서 억압된 '어른'으로 향했을 것이라고 짐작 하게 된다. 그럼 '아이 속의 어른'은 어떤 무의식적 역동을 의 미하는 것일까? 여기서 다소의 상상이 필요하다. 이는 아마도 루소가 아이 때에 '어른이 되고자 하는 소망'을 가지지 않았나 짐작하게 된다. 즉 이전 논문(Lee와 Yoon 2021)에서 밝혔듯 이, 루소의 고착된 소망은 이상화된 어머니 대상을 복원, 소 유하는 것이고, 이 소망이 구현된 회화가 〈꿈 Dream 1910〉이 라고 하였다. 그럼 이 소망과 상응하는 또 다른 소망은 바로 '어머니를 소유하기 위해 (아이)인 루소가 어른이 되는 것'이 아닐까? 이는 오이디푸스 콤플렉스의 기본적인 알고리즘이 며, 루소는 이 시기에 강하게 고착되어 있는 삶을 살았다. 저 자는 외래에서 무의식적 자극에 예민한 환자들을 볼 때, 아

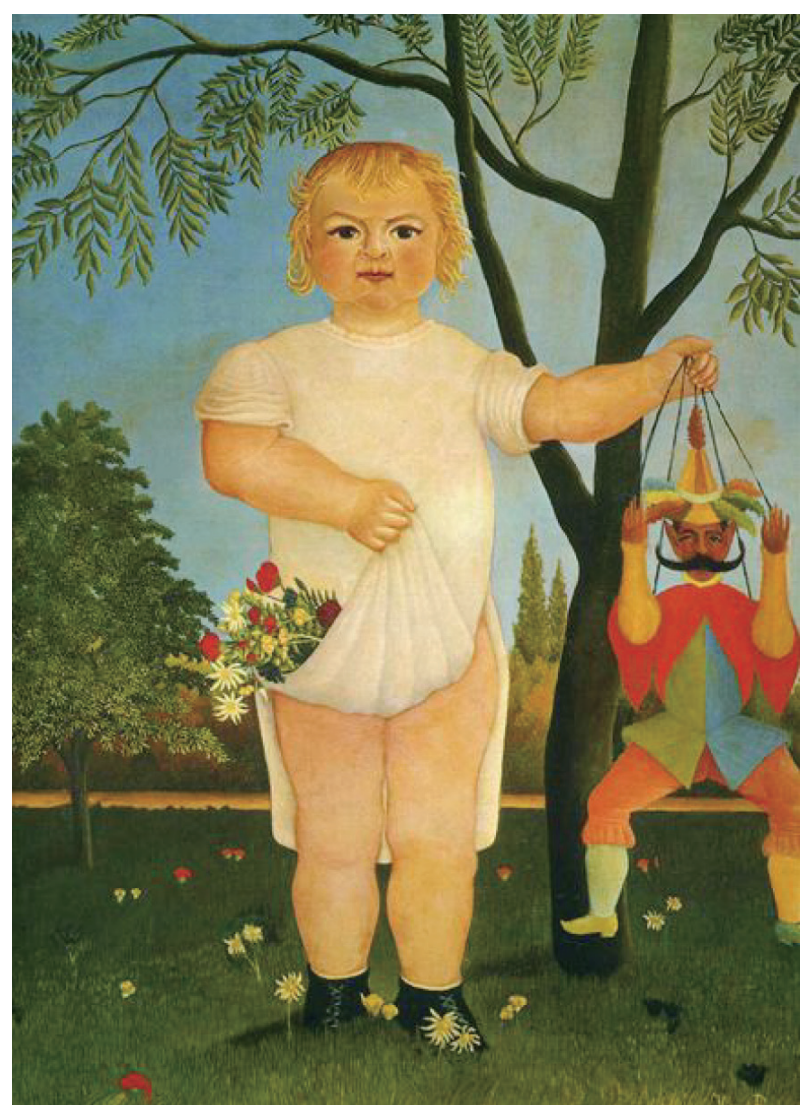

Figure 10. An exemplum: To Fete Baby! (Child with Puppet) (1903), $100 \times 81 \mathrm{~cm}$. Switzerland, Kusthalle Winterthur.
이를 보면 어른 같다는 말을 하는 환자들을 가끔씩 본다. 불 안을 주로 호소했던 30대 여자는 아이가 어른의 모든 것을 다 알고 있을 것이라는 말을 하였는데, 이는 후에 자신의 어 릴 때 모습의 투사로 밝혀졌다. 〈인용문 6>에서 암시하듯 루 소는 이러한 성향이 더 강할 뿐이다. 따라서 그의 회화에서 보이는 어린이에 대한 시각적 타협 형성은 현실에서 보이는 아이의 몸과 무의식적 충동에서 느껴진 어른의 모습이 혼재 된 모습으로 이해된다.

Figure 10은 이러한 무의식적 연결을 지지하는 듯하다. 마 치 괴물과 같은 크기의 아이의 얼굴은 어른의 모습이지만, 루소가 소망하는 나무와 꽃, 잔디 등이 가득하다. 무의식적 환상과 평행한 공간에서 '아이’의 자극은 루소에게 자신이 어 릴 때 소망했던 '성인'의 모습이 그려진다. 또한 흥미로운 것 이 어릴 때 역시 소망했을 것 같은 '어른을 조종'하는 모습이 피에로를 잡고 있는 모습으로 표현되었다. 이 작품의 제목이 ‘축제의 아기에게'라 불리는 것은 우연이 아닌 것이다. 이러 한 전이 현상을 설명하는 또 하나의 근거가 있다(Figure 11). 이 그림은 현재 사진만으로 남아있는 작품으로 루소의 사랑 스런 손녀를 그린 것으로 알려져 있다(Le Pichon 1982). 이 사

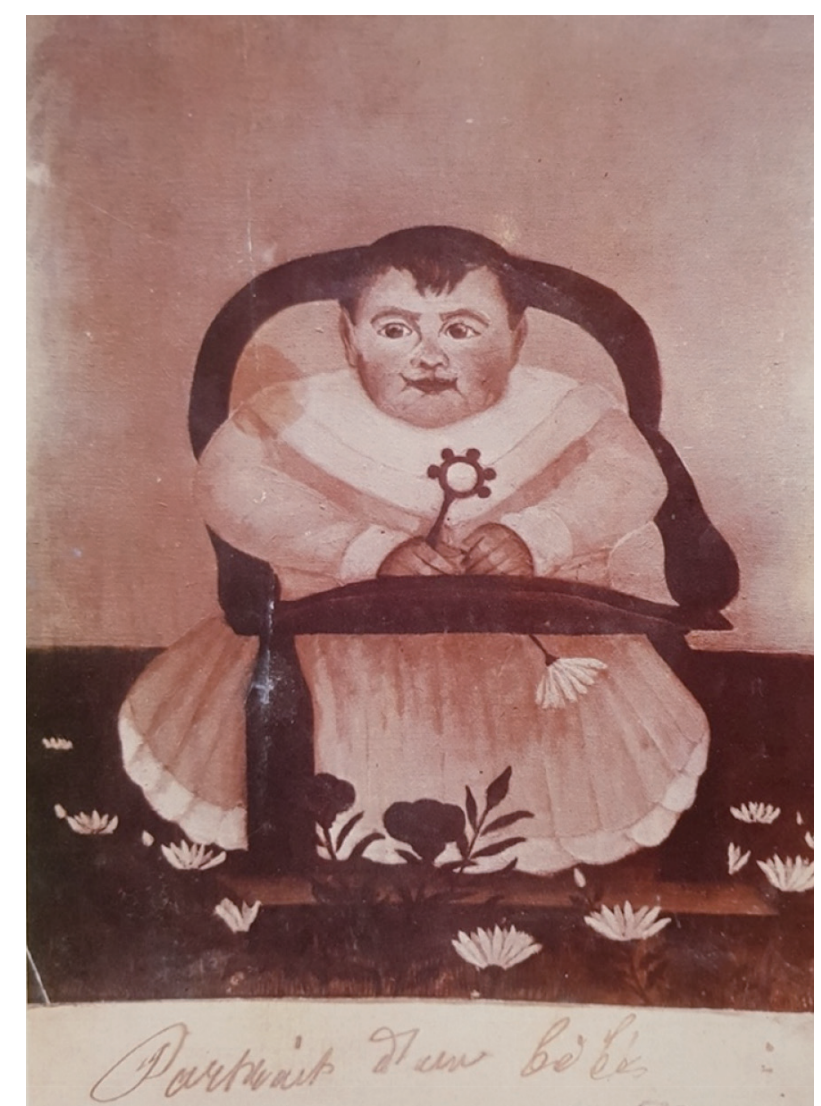

Figure 11. Portrait of Baby. Photograph of a painting that disappear (Pichon 1982). 


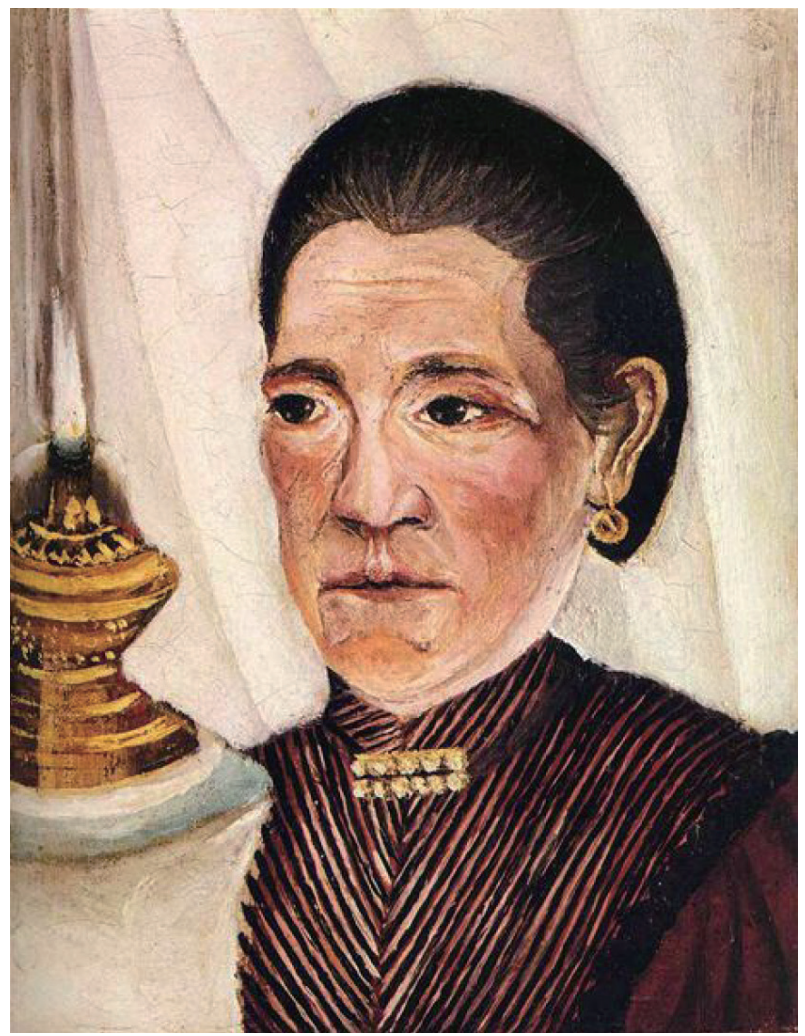

Figure 12. Portrait of the Artist's Second wife Josephine (1903), $22 \times 17 \mathrm{~cm}$. Paris, Musee Picasso.

진은 앞의 아이 그림과 달리 '아이'의 귀여운 모습이다. 손녀 앞에서 루소는 현실의 모습인 할아버지인 것이며, 자신의 과 거가 투사되면 안되는 것이다.

인물화의 특징 3)에 대한 무의식적 관점에서의 설명 역시 〈인용문 6〉에서 힌트를 얻을 수 있다. 루소는 그림을 그릴 때 사진을 많이 이용하였다(Le Pichon 1982). 사진은 사람 을 직접 대면했을 때와 다르게 전이와 같은 무의식적 충동 을 조절할 수 있다. 즉, 그의 표피적인 대인 관계 이상으로 의식/무의식적 감정을 억압, 즉 격리(isolation)시킬 수 있는 자유로움이 있다. 이러한 무의식적 역동이 회화에 나타나지 않을까? 따라서 루소는 사람들을 (그의 일상 대인 관계처럼) 무생물과 같이 그린다. 즉 로봇과 사람들을 붙이는 조합이 되는 것이다. 이런 현실적 요소에 많은 영향을 받지만 감정 표현에 있어 상반되는 회화는 1903년에 그린 Figure 12이다. 그의 두번째 부인인 조제핀의 초상으로 그녀가 죽기 직전에 그린 것이다. 병과 가난으로 죽어가는 부인의 모습에서 루소 는 전이 충동보다 현재 부인의 모습이 중요하다. 곧 자신의 눈에서 사라질 부인의 현재 병약한 얼굴이 지나칠 정도로 자세하게 묘사되어있다-물론 그의 관심은 얼굴이기 때문에 몸과 분리된 듯하다-.

무의식적 관점에서 인물화를 정리하면 다음과 같다. 풍경

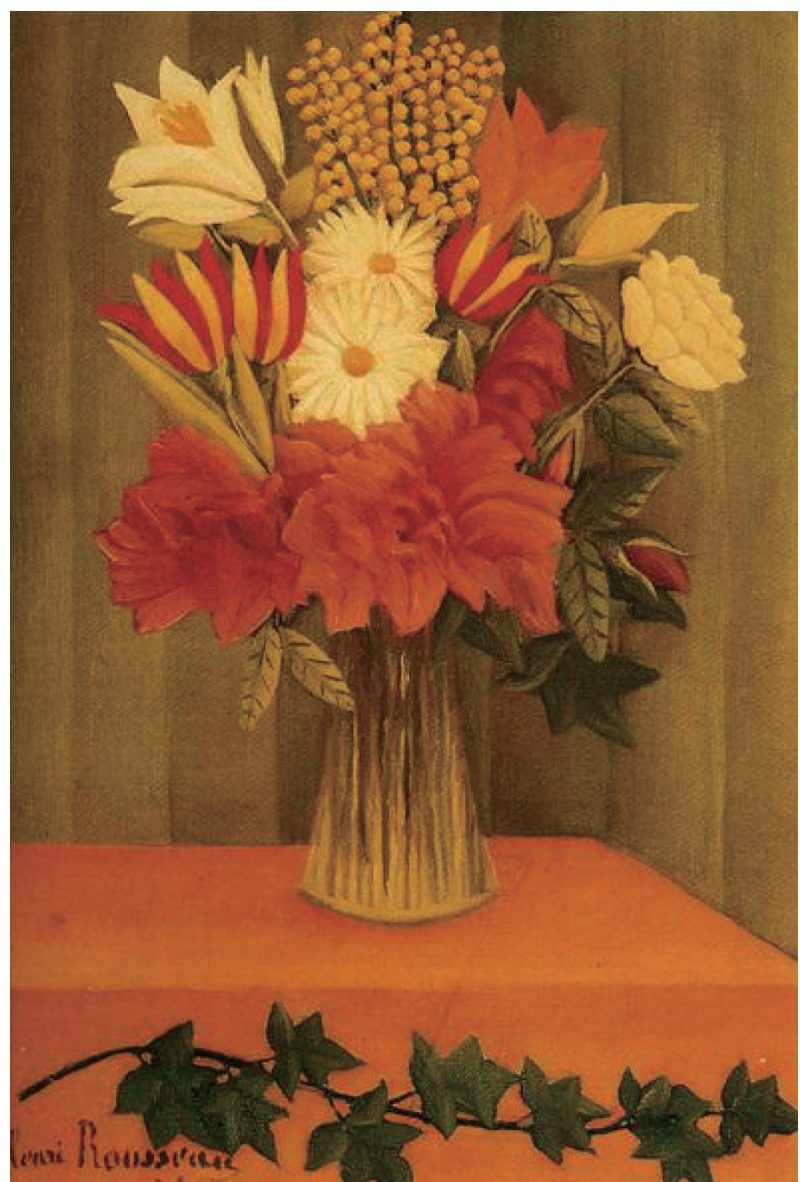

Figure 13. Bouquet of Flowers with and Ivy Branch (1909), $46.4 \times 33$ $\mathrm{cm}$. New York, The Museum of Modern Art.

화가 공간의 전이적 요소가 현실의 요소와 공존한 것처럼, 인물화 역시 대상에 대한 전이적 요소가 대상의 실제 모습, 여건과 반응하여 함께 표현되었다. 단지 인물화의 실제적인 조건-직접 보는 것, 아이, 의뢰자의 요구 등-은 다양한 층위 의 무의식이 자극되어 타협된 형태로 표현되었다. 이러한 관 계에서의 무의식적 역동은 풍경화처럼 개별적 양식으로 나 타난다.

\section{정물화}

지금까지 알려진 루소의 정물화는 총 12점이다. 그에게 정 물화는 다른 장르의 것과 비교하면 다소 낮선 느낌이다. 이 국적인(exotic) 정글 연작이나 어린아이 그림같이 단순한 풍 경화와 다른 인상을 주며, 앞서 설명한 인물화의 특징적인 형태가 보이지 않는다. 오히려 루소의 정물화는 다른 장르보 다 자극적이지 않고 차분한 느낌을 준다. 물론 그의 독특하 고 화려한 색감과 사물의 단순한 배치는 루소만의 흐름이 기 저에 있음을 시사한다(Figure 13, 14).

그러면 앞서 설명한 것처럼 풍경화나 인물화의 현실적인 


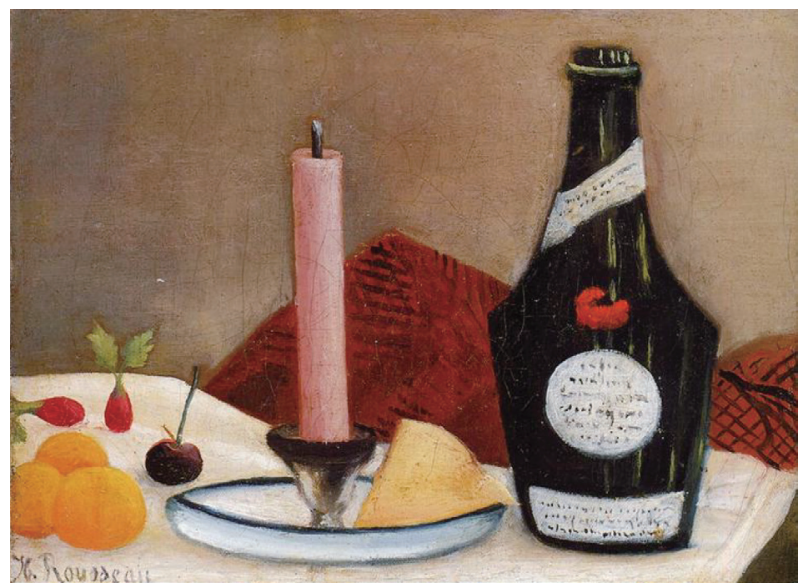

Figure 14. The Pink Candle (1909 10), $16.2 \times 22.2 \mathrm{~cm}$. Washington, DC, The Phillips Collection.

조건과 루소의 무의식이 반응하여 그의 회화에 영향을 주었 다면 과연 정물화에는 어떤 영향을 주었을까? 이 설명을 하 기 위해 루소의 풍경화 설명을 위해 인용했던 〈인용문 1〉을 상기해보면 어떤 단서를 찾을 수 있을 것이다. 앞서 설명했 듯, 루소에게 자연은 안식처의 역할을 하고, 자신의 어머니 대상과 연결된 무의식적 환상으로 들어가는 통로 역할을 하 였다. 〈인용문 1〉에서 말했듯이, 그는 (정글 연작에서 어머니 대상 소유를 소망 했듯) 자연을 '소유’하고 싶었다. 하지만 현 실의 제한은 늘 존재한다. 예를 들면, 사람은 움직이고, 날씨 는 늘 변하며 이와 반응한 색채 역시 불안정하다. 이러한 가 변적인 요소들은 실제로 자신만이 소유하고 싶은 '순간'을 좌절시킨다. 풍경화에서 설명했듯 그에게 풍경은 ‘대상'으로 역할을 하기 때문에 그의 현실적인 고통, 무의식적 갈등의 도피처이다. 즉 그에게 자연은 외부적인 자극과 내부적 불안 정함의 투사물이 섞인 공간인 것이다. 이러한 관점에서 정물 화는 최소화된 자극을 위한 조건을 충족시킨다. 즉 그는 시 간이 지나감으로 소유할 수 없는 순간의 아쉬움을 고정된 세팅-정물화를 still life로 부른다-을 통해 만족할 수 있으 며, 그가 소유하고 싶은 오브제를 모아 안정적으로 집중할 수 있는 것이다. 따라서 그에게 정물화는 불안정함을 최대한 배제하거나, 조작할 수 있는 오브제의 세팅으로 불안정한 감 정을 정리할 수 있는 조건의 회화인 것이다. 이러한 정물화 의 현실적인 조건들이 앞서 말한 정글 연작이나 풍경화, 인 물화와 다른 이유인 것이다. 정물화는 다른 그의 그림과 다 르게 사람들을 만족시킨 것 같다(Adriani 2001). 이러한 맥 락에서 다소 벗어나 있는 정물화(Figure 15)는 저자의 무의 식적 관점에서의 설명을 지지하는 듯하다. 1908년 그린 이 정물화는 다른 정물화와는 다르게 이국적인(exotic) 열대 과 일로 가득 차 있다. 안정적이지 않고 쏟아져 내릴 듯한 구도 는 세잔의 정물화를 연상시킨다. 이러한 차이는 아마도 자극

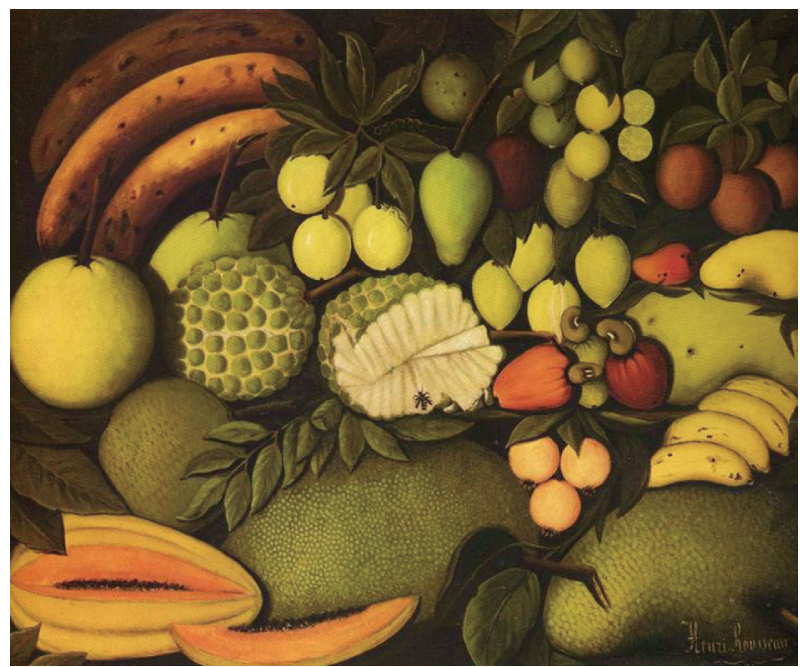

Figure 15. Still life with Exotic Fruit (1908). Private Collection.

요인의 차이인 듯하다. 당시 루소는 정글 연작에 심취해 있 었다고 볼 때, 정글의 과일로 인해 그의 불안정한 무의식의 역동이 표현되지 않았을까 한다. 놀라운 세부 묘사는 그가 정글의 회화와 연결되어 있음을 시사한다. 하지만 불안정한 오른쪽 상부의 과일을 왼쪽의 하부의 과일이 지지하여 새로 운 균형감을 만들고 있는 사실로 볼 때, 기존 정물화의 안정 적인 흐름을 유지한다.

정리하면, 루소 회화 양식에서 다소 벗어난 듯한 정물화는 정물화만의 특별한 조건이 루소의 무의식과 반응하여 표현 된 것으로 짐작된다. 이러한 안정적인 세팅에서 루소는 자신 의 무의식적 에너지를 오브제에 투사하여 자신 만의 독특한 정물화 양식을 만들었다.

\section{결 론}

저자는 본 논문에서, 이전 논문에서 밝힌 루소의 삶을 지 배했던 어머니 대상을 향한 무의식적 환상이 풍경화, 인물화, 정물화 등 각 장르의 현실 조건에 따라 의식/무의식적으로 반응하면서 다양한 모습으로 표현되었음을 주장하였다. 풍 경화는 정글 연작과 무의식의 층위와 정도가 다르지만, 정글 회화처럼 어머니 대상을 향하고, 이를 복구하려는 무의식적 소망이 타협 형성되어 표현되었고, 그 과정에서 공간에 투사 된 의식/무의식적 내용물들은 가공(processing)되어 단순화 (simplification)되었다. 저자는 이 과정에서 개별적인 양식과 공간 표현이 루소의 무의식 역동과 깊은 관련이 있다고 주 장하였다. 인물화를 그릴 때 조건은 타 장르와 다르게 루소 의 의식/무의식적 대인 관계의 역동 및 전이 현상이 다양한 층위에서 표현되었고, 이 역시 무의식적 역동이 개별적 양식 형성에 깊은 영향을 주었다고 주장하였다. 정물화(still life)만 
의 조건은 루소만의 무의식적 역동이 오브제에 안정적으로 투사되어 조화로운 구조로 묘사되었다. 언뜻 보기에 루소의 그림이 아닌 듯 느끼는 것은 타 장르의 조건보다 무의식적 역 동이 조절됨을 시사하며, 이 역시 루소만의 독특한 공간 및 양식을 형성하였다.

위 결론을 통해 몇 가지 중요한 내용을 알 수 있다. 첫째, 개별적인 무의식 역동은 개별적인 공간, 양식을 만들어 낸다 는 것이다. 세잔이나 고흐, 고갱 등 동시대의 진취적인 화가 들은 모두 이 라인에서 '개별적 존재'를 표현하였다. 둘째, 루 소 회화의 특징인 단순화는 미술사가들이나 평론가들이 일 관적으로 주장했던 '소박한(naive), 원시적인(primitive)'의 묘사를 설명한다. 여기서 '어린 아이'와 같은 시선과 그 표현 은 무의식적 관점에서 '자유로운 퇴행의 능력'을 의미하며, 루소는 이 지점의 무의식적 에너지를 응축하여 표현하였다. 이는 초현실주의, 추상 회화 등 모더니즘 회화의 출발점을 시사한다. 이에 대한 자세한 설명은 추가 논문에서 밝힐 것 이다. 세째, 루소의 풍경화, 인물화, 정물화는 앞서 설명했듯 이 타협형성된 무의식적 역동과 현실 요소가 혼재되어 표현 되었다. 이는 어떤 객관적인 현실이나 공간이 아닌 정신 분석 의 임상에서 중요시 하는 개별적인 심리적 현실(psychic realism)을 시각화한 것으로, 무의식과 현실이 혼재되어 표현한 (넓은 의미로서) 언캐니(Uncanny) 회화의 시작 지점으로 주 장할 수 있는 것이다.

본 논문의 제한점은 루소에 대한 이전 논문(Lee와 Yoon 2021)과 유사하다. 무의식적 관점에서 보이는 방법론의 한계, 루소 자료의 부족 및 신뢰성의 문제, 자신 그림에 대한 설명이 나 기존 미술사적 방법론에 대한 설명의 부족 등이다. 또한 무 의식적 관점이나 맥락이 루소 회화 전부를 설명하지 않는다. 예술가의 창조성에 대하여 무의식 역동 뿐만 아니라 예민함, 재능, 기술적인 숙련도 등 다양한 요소들이 작용한다(Baudry 1984). 이러한 제한점은 앞으로 정신분석적 임상이 강화된 논 문이나 이와 관련된 축적된 연구로 채울 수 있을 것이다.

저자는 이번 논문에서 루소의 회화가, 모더니즘 회화가 추 구했던 개별적 존재를 향한 흐름에서 중요한 위치임을 설명하 였고, 무의식적 관점이 이 주장에 중요한 근거가 될 수 있음을 주장하였다. 루소는 어쩌면 그가 스스로에게 말했듯 '그는 자 신의 세기(century)에 속한 화가가 아닌듯하다(Belli 등 2015). 저자는 후속 논문에서 루소가 맞닿아 있는 미술사적인 지점들 을 무의식적 관점에서 분석함으로써 루소의 저 허언같은 말 이 전혀 근거가 없는 이야기가 아님을 주장할 것이다.

\section{Acknowledgments}

None

\section{Conflicts of Interest}

The authors have no potential conflicts of interest to disclose.

\section{Author Contributions}

Conceptualization: all authors. Investigation: Lee Hyun Kwon. Methodology: Lee Hyun Kwon. Project administration: Lee Hyun Kwon. Writing — original draft: Lee Hyun Kwon. Writing — review \& editing: all authors.

\section{ORCID iD}

Hyun Kwon Lee https://orcid.org/0000-0002-6193-2552

\section{REFERENCES}

Adriani G, Köln B. Henri Rousseau. Kleager S, Marsh J, translator. New Haven: Yale University Press;2001. p.8-279.

Auchincloss EL, Samberg D. Psychoanalytic terms and concepts. New Haven: Yale University Press;2012. p.206.

Baudry F. An essay on method in applied psychoanalysis. Psychoanal Q;1984;53:551-581.

Belli G, Cogeval G, Barisoni E, Metcalfe P, Fondazione Musei civici di Venezia, Palazzo Ducale. Henri Rousseau: archaic naivete. Milan: 24 ORE Cultura;2015. p.21-279.

Brenner C. The mind in conflict. New York: International University Press;1982. p.109-119.

Essers V. Henri Matisse. Kim BH, translator. Seoul: Maroniebooks;2006. p.83.

Foster H. Compulsive beauty. Cho JY, translator. Paju: Art Books;2020. p.13-297.

Freud S. Three essays on the theory of sexuality. SE 7. London: Hogarth Press;1905. p.123-246.

Freud S. Analysis of a phobia in a five-year-old boy. SE 10. London: Hogarth Press;1909. p.5-149.

Freud S. Findings, idears, problems. SE 23. London; Hogarth Press;1938. p.300.

Gombrich EH. The story of art (15th ed). Beak SK, Lee JS, translator. Seoul: Yekyoung Publishing Co.;1995. p.586.

Greeberg C. Art and culture: critical essays. Cho JY, translator. Busan: Kyungsung University Press;2011. p.155-159.

Ireson N. Interpreting Henri Rousseau. London: Tate Publishing; 2005. p.5-77.

Kuspit DB, Beuys J, Warhol A, Malevič K, Mondrian P, Duchamp M, et al. The cult of the avant-garde artist. Cambridge: Cambridge University Press;1997. p.1-192.

Lee HK, Yoon HR. Study for Cezanne in the perspective of the unconscious. Psychoanalysis 2019;30:50-61.

Lee HK, Yoon HR. Study for artist Henri Rousseau in the perspective of the unconscious: centering on his jungle series. Psychoanalysis 2021; 32:21-35

Le Pichon Y. The world of Henri Rousseau. Neugroschel J, translator. New York: Arch Cape Press;1982. p.10-278.

Stabenow C. Henri Rousseau. Lee YJ, translator. Seoul: Maroniebooks; 2006. p.6-95.

Uhde W. Recollections of Henri Rousseau. Los Angeles: Getty Publications;2018. p.7-76. 